\title{
Neoliberal Düzende Artan Kırılganlıklar: Pandemi Döneminde Mülteci Sağlı̆̆1
}

\author{
Şebnem Köşer Akçapar ${ }^{1}$ ve Aysima Çalışan ${ }^{2}$ \\ $\ddot{O} z$
}

\begin{abstract}
Koronavirüs salgmı, sosyal hayatın her yönünü etkileyerek, çok, boyutlu bir krivyarattı. Göcmen ve mültecilerin dabil olduğu kerrlgan gruplar üzerinde, kriz̨in etkileri daha ăgr hissedildi. Bu nitel çalşmada, risk toplumu ve neoliberalizm etrafindaki kuramsal temele dayanarak, pandeminin Türkiye'de yasayan Suriyeli mültecilerin üzerindeki etkisini araştırldd. Calısma sonuclarna göre, pandeminin en çok Suriyeli mültecilerin geşim kaynaklarm etkilediği görüldü. Geçim kaynaklarndaki azalmanı, barmma, sağhk ve eğitim hiz̆metlerine erisimi de aksattiğg ortaya konuldu. Gelir elde etmek veya mevcut gelirlerini korumak için, başka mülteciler ile evlerini birlesstirme ve/veya enfekte olduğunu saklayn ise gitme gibi yeni stratejilerin belirlendiği ögrenildi. Ayrnca,

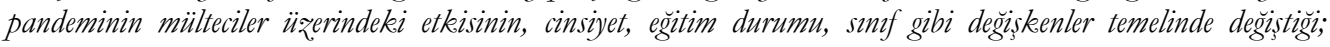
dolayısıyla çoklu kırlganlıklarn ortaya çıktı̆g görüldü. Sonuç olarak, pandemi ile mücadele etmede, mülteci gruplar da içeren bir halk sağğ̆ğ planlamasinin önemi vurgulandı.
\end{abstract}

Anahtar Kelimeler: Suriyeli mülteciler; COVID-19; koronavirüs; halk sağh̆̆g; kırnlganlık; Türkiye

\section{ABSTRACT IN ENGLISH}

\section{Growing Vulnerabilities in the Neoliberal Order: Refugee Health During the Pandemic}

The COVID-19 pandemic has become a multidimensional crisis affecting every aspect of social life. Migrants and refugees are particularly vulnerable to the impacts of this crisis. By referring to the theoretical framework on risk. society and neoliberalism, this qualitative study investigates the impact of the pandemic on Syrians under temporary protection (SuTP). Findings suggest that the pandemic has led to widespread loss of livelihoods and unemployment among SuTPs which has simultaneously decreased their access to services such as shelter, health, and education. Nonetheless, the respondents have devised new strategies, such as sharing their homes with other refugees or concealing their contracting with COVID-19 in order to prevent losing their jobs. The impact of the outbreak on refugees differs depending on variables such as gender, education level, and social class; hence, multiple vulnerabilities have emerged. Ultimately, this study highlights the importance of public health planning models by involving all migrant and refugee groups for a more successful and effective crisis management.

Keywords: Syrian refugees; COVID-19; coronavirus; public health; vulnerability; Turkey

\section{Giriş}

Birbiri ardına gelen toplumsal, ekonomik ve teknolojik gelişmelerin etkisi ile çözülmeye başlayan geleneksel kurumlar, zaman içinde yerini modern kurumlara bırakmıştır. Bu

\footnotetext{
${ }^{1}$ Prof. Dr. Şebnem Köşer Akçapar, Ankara Sosyal Bilimler Üniversitesi, Sosyoloji Bölümü Öğretim Üyesi ve Küresel Göç Merkezi Araştırmaları ve Uygulamaları Merkezi Müdürü, Türkiye. E-mail: sebnem.akcapar@asbu.edu.tr.

${ }^{2}$ Aysima Çalışan, Yüksek Lisans Öğrencisi, Ankara Sosyal Bilimler Üniversitesi, Uygulamalı Sosyal Araştırmalar, Türkiye.

E-mail: aysima.calisan@student.asbu.edu.tr.
} 
dönüşümü simgeleyen modernite olgusu, bireylerin yaşam kalitesini yükselten sınırsız fırsatlar sunmasından dolayı birçokları tarafindan kucaklanmıştır. Ancak, özellikle yirminci yüzyılın insan kaynaklı bazı felakatleri beraberinde getirmesi, modernitenin sunduğu firsatlar kadar potansiyel tehditler de barındırdığını ortaya çıkarmıştır. Bu dönemde yaşanan savaşların, ekolojik felaketlerin ve nükleer silahlanmanın sebep olduğu yıkım, modernitenin gizli perdesini aralayarak, onun karanlık yüzünü göstermiştir (Giddens, 1991: 7-9). Belirsizliklerle ve bilinmezliklerle dolu olduğu anlaşılan modernite, ayrımcıllı̆̆1 ve ötekileştirmeyi derinleştirerek, toplumsal kutuplaşmayı artırmıştır. Bu değişimden ise en çok toplumsal güven kavramı etkilenmiş ve insanlar, geleceğin getireceklerine şüpheyle bakmaya başlamıştır.

Modernitenin, 21. yüzyılda yarattığ1 en büyük belirsizliklerden biri olarak karşımıza çıkan koronavirüs, Çin'in Hubei eyaletinin başkenti olan Wuhan'da tespit edildikten kısa süre sonra, özellikle insan hareketliliğinin ve büyük nüfuslu ülkelerin barındırdığı göçmen stoklarının etkisiyle bütün dünyaya hızla yayılmıştır (Sirkeci ve Yüceşahin, 2020). Dünya Sağlık Örgütü tarafindan 11 Mart 2020'de küresel salgın olarak ilan edildikten tam bir y1l sonra, dünya çapında 117 milyon vaka görülmüş ve 2.6 milyon insan virüse bağl1 olarak hayatını kaybetmiştir (WHO, 2020; WHO, 2021). Ancak, küresel salgın, yalnızca milyonlarca insanın etkilendiği bir sağlık sorunu şeklinde yorumlanmamalıdır. Pandemi dönemindeki süreç ve pandemi sonrası dünyaya ilişkin tahminler, koronavirüs salgınının aynı zamanda ekonomik, sosyolojik ve psikolojik açıdan yıkıcı sonuçları olacağına işaret etmektedir. Küresel ekonominin küçülmesi, işgücü kayıplarının artması, dünya nüfusunun \%9.1’i ile \%9.4'ünün aşırı yoksulluğun kıskacında yaşamaya başlaması, bu sonuçlardan yalnızca birkaçıdır. (ILO, 2020; World Bank, 2020). Bununla birlikte, pandeminin sonuçlarının herkesi eşit bir şekilde etkilemediği, toplumdaki mevcut eşitsizlikleri derinleştirerek, kadınların ve göçmenlerin dahil olduğu kırılgan gruplar üzerinde daha ağır etkiler yarattığ1 vurgulanmaktadır (Köşer Akçapar, 2020).

Birleşmiş Milletler'e göre pandemi, sığınmacılar, mülteciler ve göçmenler için sağlık, istihdam, eğitim, barınma ve korunmayı içeren çok boyutlu bir kriz halini almıştır (Guterres, 2020). Örneğin, salgınla mücadele kapsamında sınırların kapatılması ve seyahat kısıtlamasının getirilmesi, hem göçmen işçilerin ülkede sıkışmasına, hem de sı̆̆ınmacıların korunma taleplerinin karşılanamamasına neden olmuştur (Ahmed, Jordan, ve Semple, 2020; BanulescuBogdan, Benton, ve Fratzke, 2020; Chetail, 2020). Birçok ülkede, düzensiz göçmenleri ve sı̆̆ınmacıları salgından koruyacak kurumsallaşmış sistem eksikliğinin olması ve bu grupların tutuklanma veya sınır dışı edilme korkusu, onları sağlık sistemine erişmekten ve COVID-19 tedavisi almaktan alıkoymaktadır (Köşer Akçapar, 2020). Yine, mülteci ve göçmen gruplarının, fiziksel mesafeye uymanın mümkün olmadığı, barınma koşullanının elverişsiz olduğu, su, gıda ve hijyen gibi temel gereksinimlerin sağlanamadığı alanlarda yaşadıkları bilinmektedir (Chen, 2020; Elisabeth, Maneesh ve Michael, 2020; Guadagno, 2020; Kluge vd, 2020; Salmani, Seddighi ve Nikfard, 2020). Bununla birlikte, bu gruplanın ev sahibi ülkelerin halk sağllğ1 planlamalarında ihmal edilmesi ve bu ülkelerin vatandaşları ile eşit düzeyde temel sağlık haklarından yararlanamamaları, mülteci ve göçmenler arasında, yerel halka kıyasla yaygın görülen koronavirüse bağlı vaka sayılarını ve ölüm oranlarını açıklamak için bir gerekçe oluşturmaktadır (Dempster vd, 2020; OECD, 2020; Vearey, Hui ve Wickramage, 2019).

Pandemi döneminde yaşanan ekonomik durgunluğun yol açtığı işten çıkarmalardan ve gelir kayıplardan, en çok kayıtdışı sektörlerde çalışan mülteciler ve göçmenler etkilenmiştir (Guadagno, 2020; ILO, 2020; OECD, 2020). Böylelikle, bir sağlık krizi olarak başlayıp sonradan ekonomik krize evrilen pandemi, sı̆̆ınmacı/mülteci ve göçmenlerin kendileri kadar, 
anavatanlarında ya da başka bir ülkede yaşayan ve onların gönderdiği işçi dövizine bağımlı olan ailelerini de tehdit eder hale gelmiştir. Mülteci ve göçmenlerin aileleri ile göç ettikleri göz önüne alındığında, pandeminin çocuklar için ciddi bir eğitim krizi de yarattığı görülmektedir. Bir kısmı kamplarda, büyük çoğunluğu şehirlerde yaşayan bu çocukların, kısıtlı teknik imkanlar sebebiyle uzaktan eğitime erişememeleri, okulsuzlaşma, çocuk işçiliği ve kayıp nesil oluşumu gibi riskleri artırmaktadır (Kirişçi ve Erdoğan, 2020; OECD, 2020; Özkul, 2020). Hak ve hizmetler noktasında ortaya çıkan bu sorunların yanı sıra göçmen ve mülteciler, salgının yayılmasından sorumlu tutularak, ayrımcılığın, göçmen karşıtlı̆̆ının ve yabanc1 düşmanlığının körüklediği söylem ve eylemlere de maruz kalmaktadırlar (Sirkeci, Özerim, ve Bilecen, 2020).

Türkiye, son y1llardaki uluslararası göç hareketlerinde hem hedef hem de transit ülke olma özelliği ile öne çıarak, birçok farklı mülteci ve göçmen grubuna ev sahipliği yapmaktadır. Pandemi döneminde, diğer ülkelerdeki duruma paralel olarak, Türkiye'de de mülteci ve göçmenler, diğer gruplara nazaran, bu sürecin olumsuz etkilerini daha fazla hissetmektedir. Örneğin, bir araştırma, COVID-19 salgının Afgan göçmenlerin sağlık durumlarının kötüleşmesine ve maruz kaldıkları ekonomik sömürünün, sosyal eşitsizliklerinin ve dişlanmanın artmasına neden olduğunu ortaya koymuştur (Bozok ve Bozok, 2020).

Bu makalenin amacı doğrultusunda deneyimlerine odaklanılacak olan Suriyeli mülteciler, 3.6 milyonluk nüfusları ile Türkiye'deki en yoğun zorunlu göçmen grubudur (BMMYK, 2020). 2014 y1lında çıkan yönetmelik ile geçici koruma statüsü verilen Suriyeli nüfusun yaklaşık \%98.4’ü kentlerde yaşamaktadır (GİGM, 2021). Genellikle kalabalık ortamlarda yaşayan ve çalışan, düşük gelir düzeyine sahip bu grubun, pandemiden nasıl etkilendiğini araştıran bazı çalışmalar mevcuttur (Akyıldız, 2020; MUDEM, 2020; Özkul, 2020; Relief International, 2020; SGDD, 2020). Bu araştırmaların ortak bulgularına göre, Suriyeli hanelerin yaklaşık \%88'inde, işten çıkarmalara veya ücret kesintilerine bağlı gelir kaybı yaşanmış; yaklaşı \% 080 'i pandemi döneminde acil ihtiyaçlarını karşılayamamıştır. Bunun yanı sıra, araştırma kapsamında görüşülen Suriyelilerin, en az \%15 ila \%26 gibi değişen oranlarda, sağlik hizmetlerinden yararlanamadıkları saptanmıştır. Son olarak, araştırmalar, hanelerin çoğunda uzaktan eğitim için gerekli teknik imkanların yetersiz olduğunu ortaya koymuştur. Bu sebeple, bazı raporlara göre her dört haneden birinde, bazılarına göre ise her iki haneden birinde yaşayan okul çă̆ındaki çocuk ve gençler eğitime erişememektedir.

Bu raporlanın sunduğu genel çerçeve, COVID-19'un Suriyeli mültecilerin geçim kaynaklanını azaltan, eğitim ve sağlık hizmetlerinden yararlanmalarını etkileyen çok boyutlu bir kriz olduğunu göstermektedir. Ortaya konulan araştırmalar, istatistiksel olarak çok değerli bulgular sunmakla birlikte, Suriyeli mültecilerin bu süreçteki deneyimlerine ve başetme stratejilerine odaklanan nitel çalışmalar ile de desteklenmelidir. Buradan hareketle, bu çalışmanın amacı, mültecilerin pandemi sürecinde karşılaştıkları zorlukları, bu zorlukları aşmada belirledikleri stratejilerini, onların deneyimleri üzerinden analiz ederek nitel veri sağlamaktır. Bunun yanı sıra, pandeminin her bir mülteci üzerindeki etkisinin farklı olacağ1 varsayımına dayanarak, bu farklılı̆̆ın, toplumsal cinsiyet, eğitim ve vatandaşlık gibi değişkenler temelinde oluşup oluşmadığının ortaya konması hedeflenmiştir. Son olarak, toplumun bir parçası haline gelen mülteci sağlı̆̆ının, genel halk sağlı̆̆ı ile ilişkisinin ortaya çıkarılması ve tartışılması amaçlanmıştır. 


\section{Kavramsal ve Kuramsal Çerçeve}

Koronavirüsün küresel boyutta yarattığı riskler ve belirsizlikler, salgını akademik tartışmaların merkezine getirerek, onun sosyolojik etkilerini analiz etmeyi gerekli kılmaktadır. Bu noktada, Alman sosyolog Ulrich Beck'in risk toplumu tezi önemli bir kuramsal taban olarak karşımıza çıkmaktadır. Beck, ikinci modernitenin belirleyici özelliğinin risk toplumunun ortaya çıkış1 olduğunu ileri sürerek, bu tezini beş dayanak noktası üzerinden temellendirir (1992: 22-24). Bunlar; (1) insan yapımı yeni mega risklerin ortaya çıkarak küresel ölçekte insanlığın varlığını tehdit etmesi, (2) küreselleşmenin ve akışkanlığın ürettiği yeni bir toplum biçiminin doğması, (3) riskin karmaşık doğasının, siyasileri ve bireyleri bilimsel bilgiye - dolayısıyla uzmanlara bağımlı kılması, (4) sosyal sınıf gibi büyük anlatıların (meta-narrative) öznesi olan sosyal kategorilerin değişerek, kendi kendini gerçekleştiren yeni bir politik özne anlayışı çerçevesinde bireyselleşmenin geçerlilik kazanması ve son olarak, (5) eşitsizliğin risk pozisyonları şeklinde yeni bir forma dönüşerek herkesi kapsamasıdır.

Beck'in sunduğu bu beş dayanak noktası, pandemi sürecinin analizi için farklı ölçeklerde geçerli ve yol göstericidir. Biraz daha detaylandırmak gerekirse, Beck'e göre, eski toplumlarda görülen, doğal afetler ve felaketlerden kaynaklanan risklerin doğası günümüz toplumlarında değişmiştir (1992: 21). Modern toplumlarda, bilim ve teknolojinin ilerlemesine paralel olarak ortaya çıkan belirsizliklerden kaynaklanan ve küresel ölçekte insanlığ1 tehdit eden yeni tip mega riskler vardır (Beck, 1992: 10-13). COVID-19 pandemisinde olduğu gibi, bu mega riskleri önceden tahmin etmek zordur; potansiyel etkilerini ve sonuçlarını hesaplamak ise öngörülere dayanır.

Pandemi ve küresel ekonomi arasında gözlemlenen karşıllılı bağlllık, tam da Beck'in işaret ettiği gibi, koronavirüs salgınının bir mega risk olduğunu göstermiştir. Küresel ekonominin daralması ve birçok insanın geçim kaynaklarını kaybetmesi neticesinde ortaya çıkan tablonun, pandemi sonrası dünyada daha da kötüleşeceğine ve 32 milyon insanın aşırı yoksulluğa sürükleneceğine vurgu yapılmaktadır (UNCTAD, 2020; World Bank, 2020). Yoksulların giderek yoksullaşması, onların pandeminin tehditlerine daha uzun süre maruz kalacağına ve gelecekte bireyleri daha fazla riskin beklediğine işaret etmektedir. Modernitenin dayattı̆̆ bu belirsizlik ortamından çıkmanın yolu ise bireyin riskleri ortadan kaldırmak için alacağ1 kararlarda - yani failliğinin gücünde - gizlidir.

Risk toplumundaki belirsizliklerden biri de düşmanın kim veya ne olduğunun bilinememesidir. T1pkı pandemi döneminde görüldüğü gibi, süper virüs bulaştırıc1ları olarak potansiyel düşmanlar her yerde, hatta evimizde bile olabilir. Pandeminin yönetilmesi bağlamında alınan tedbirlerin riski yok etme konusunda yetersiz kalmas1, bu görünmez düşmanın sadece bireyin sağlık hakkını değil; aynı zamanda diğer tüm temel haklanını da tehdit etmesine neden olur. Bireyler, belirsizliklerin ve tehditlerin sonuçlarını minimize etmek için kendi güvenliklerini öncelerler (Delibaş, 2015). Güvenliğin öncelenmesi, biz ve ötekiler arasına çekilen çizgilerin keskinliğine dayanır. Mülteci ve göçmenlerin yeri, bu süreçten en fazla etkilenen gruplar arasında yer almalarına rağmen, öteki konumlarından dolayı günah keçisi ilan edilebilir; dolayısıyla, virüsü bulaştırmakla ve yaymakla suçlanarak, halk sağlığına zararlı düşmanlar olarak görülebilirler.

Ayrıca, riskler ve tehlikeler belirli bir mekanla, zamanla, sınıfla veya toplulukla sınırlı değildir (Beck, 1992: 13). Ancak, bu durum mevcut eşitsizliklerin ortadan kalktığ1 şeklinde bir yanılsamaya sebep olmamalıdır. Bireylerin, risklerin sonuçlarından etkilenme düzeyi, 
kimliklerine göre artmakta veya azalmaktadır; dolayısıyla, eşitsizlik halen varlığını sürdürmektedir. Nitekim, SARS-CoV-2 virüsüne yakalanma riski herkes için geçerlidir. Ancak, bu risk, cinsiyet, sınıf ve statü gibi demografik belirleyiciler temelinde, sosyal olarak kırilgan bazı gruplar için daha yüksektir. Bir diğer deyişle, kimlikleri temelinde dezavantajlı risk pozisyonlarına sahip bireyler, pandemi de dahil olmak üzere tüm risk ve tehlikelere karşı daha savunmasızdır. Çünkü, toplumun diğer kesimlerinin aksine, bu gruplar, kendilerini risklerden ve tehlikelerden korumak için yeterli kaynaklara sahip değillerdir ve bu sebeple özyönetim sürecine eşit bir şekilde katılamazlar.

Pandemiye bağlı ekonomik durgunluk döneminde, kadınlar erkeklere oranla, göçmen ve mülteciler ise yerel halka oranla iş kayıplarından daha fazla etkilenmiştir (ILO, 2020). Çünkü, kadınlar, göçmen ve mülteciler, neoliberal sistemin düzenli olarak düzensiz işlerde, güvencesiz olarak çalıstırılan emekçileri, bir diğer deyişle, prekaryalarıdır (Standing, 2014). Neoliberal sistem, sosyal refah programlarını özelleştirerek, kadınların üzerindeki toplumsal cinsiyete dayalı sorumlulukları artırmış ve onları yarı-zamanlı ve düşük ücretli işlerde çalışmaya mahkum etmiştir (Armstrong, 1996; Scharff, 2016; Shields, 1996). Mülteci ve göçmenler için de neoliberal süreç benzer şekilde ilerlemiştir. Emek piyasasına girişteki engellerin, dil ve bilgi eksikliğinin ve vatandaş olmamanın getirdiği zorluklar sonucu yerel halkla formel işler için rekabet edilememesi ve neoliberal sistemin sosyal destek programlarını kaldırması, bu grupları prekaryanın bir bileşeni haline getirmiştir (Jamil, vd, 2016; Krahn, vd., 2000; Matoo, Neagu ve Özden, 2006; Shields, 1996).

Pandemi ile iş yerlerinin faaliyetlerini durdurması ve 'esnek' çalışma koşullarına geçilmesiyle, emek piyasasında ilk gözden çıkarılanlar elbette güvencesiz koşullar altında çalışan kadınlar, göçmenler ve mülteciler olmuştur. Bunun sonucu olarak, göçmen ve mülteciler, derin bir yoksullukla karşı karşıya kalmış; kadınların ev içindeki mevcut yüklerine, yaşlı bakımı ve çocukların eğitimi gibi toplumsal cinsiyete dayalı yeni sorumluluklar eklenmiştir. Bazı hanelerde bu yükler, eğitimden mahrum bırakmak pahasına, kız çocuklarının üzerinde yıkılmış; erkek çocuklar ise, aileleri tarafından, hanenin geçim kaynaklarını kaybetmesi sonucu evin geçimini sağlamak için çocuk işçiliğine yönlendirilmiştir.

\section{Yöntem}

İncelenen olguya ilişkin daha detaylı bir anlamlandırma sunduğu için bu çalışmada nitel araştırma yöntemi benimsenmiştir (Merriam, 2009). Araştırma sırasında, veriler derinlemesine mülakat tekniği ile toplanmıştır. Saha araştırmasında, ilk olarak mülakatlar yüz yüze gerçekleştirilmek istenmiştir. Bu doğrultuda, Ankara'nın Altındağ ilçesindeki Suriyelilerin yoğunluklu olarak yaşadığı birkaç mahallede üç gün süren bir pilot çalışa yürütülmüştür. Ancak, pandemi koşullarında katılımcılara ulaşmanın zor olması ve ulaşılan kişilerin virüse yakalanma endişesi ile görüş̧mek istememesi gibi sebeplerden dolayı katılımcılara ulaşmak için yeni bir strateji belirlenmiştir. Buna göre, katılımcılara, Suriyeli mülteciler tarafindan kurulan ve üyelerinin çoğunlukla Suriyelilerden oluştuğu WhatsApp, Instagram ve Facebook grupları üzerinden ulaşılmıştır. Bu gruplarda, araştırmanın içeriği, amacı, yöntemine ve araştırmacının iletişim bilgilerine ilişkin Türkçe ve Arapça olarak kısa bir duyuru paylaşılmışır. Araştırma hakkında bilgi almak ve araştırmaya katılmak isteyenlerle kısa görüşmeler yapılmıştır. İlk etapta, ilgi gösteren kişilerin çoğunluğunun sosyal medyayı aktif olarak kullanan 18-25 yaş aralığındaki üniversite öğrencileri olduğu görülmüştür. $\mathrm{Bu}$ durumun örneklemde bir kümelenmeye neden olacağı endişesi ortaya çıkmış; dolayısıyla, bu yaş aralığındaki gruptan 
sadece birkaç kişi ile mülakatlar yapılmıştır. Duyuru, düzenli olarak sosyal medya gruplarında paylaşılıp dolaşımda tutularak, farklı yaş ve meslek gruplarından kişilerin de araştırmayı görmesi hedeflenmiş; böylelikle, örneklemin çeşitliğinin artması sağlanmıştır.

Kasım-Aralık aylarında, bu gruplar üzerinden araştırmacılara ulaşan 20 katılımcı ile görüşme takvimleri oluşturulmuştur. Katılımcının tercihi doğrultusunda, Zoom ve Whatsapp platformları üzerinden görüntülü/sesli görüşme yapılarak veri toplanmıştır. Zoom uygulamasını tercih eden katılımcılara, araştırmacı tarafından toplantı bağlantıları gönderilmiş; WhatsApp'ı tercih edenler ile randevu saatinde direkt aramalar yapılmıştır. Görüşmeler, Türkçe ve İngilizce olarak araştırmacılar tarafından, Arapça olarak bir tercüman aracıllı̆ıyla gerçekleştirilmiştir. En kısa görüşme 33 dakika, en uzun görüşme 1 saat 15 dakika sürmüştür. Ankara'da görüşülen katılımcılar dışında diğer katılımcıların, Suriyelilerin yoğun olarak yaşadığ1 İstanbul, Gaziantep, Hatay, Mersin ve Kilis illerinde ikamet ettiği öğrenilmiştir.

Katılımcıların rızası doğrultusunda alınan ses kayıtları çözümlendikten sonra, deşifreler MAXQDA 2020 programına yüklenmiş ve araştırmanın amacı doğrultusunda, belirli kodlar etrafinda tematik analize tabi tutulmuştur. Tematik analizin, verilerdeki benzerliklere ve farkl1l1klara vurgu yaparak, görüşülen gruba ilişkin derinlemesine bir değerlendirme yapma imkanı sunması, bu araştırmada önemli bir kolaylaştırıcı olmuştur (Creswell, 2015; Braun \& Clarke, 2006).

\section{Bulgular ve Tartışma}

Bu bölümde, ilk olarak katılımcıların demografik özelliklerinden, göç hikayelerinden ve pandemi öncesindeki yaşam koşullarından kısaca bahsedilmiştir. Ardından, pandemi sürecinde temel haklarından yararlanma ve hizmetlere erişme deneyimlerine bakarak, pandeminin mülteciler üzerindeki etkisi ve bunun farklı boyutları ortaya konmuştur.

\section{Katılımcılar, Göç Hikayeleri ve Pandemi Öncesi Yaşam Koşulları}

Katılımcılann yaş, cinsiyet, eğitim ve vatandaşlık durumuna ilişkin demografik bilgileri Tablo1'de verilmiştir. Araştırma kapsamında, yaşları 22 ve 64 aralığında değişen on bir erkek ve dokuz kadın katılımcı ile görüşülmüştür. Katılımcıların on biri Halep’ten, dördü Şam’dan, dördü Lazkiye'den ve biri de Tartus’tan Türkiye’ye gelmiştir. Göç etme nedenleri, savaşın gündelik hayatın güvenli düzenini bozması sonucu sürekli korku ortamının oluşması, insan güvenliklerinin ve yaşamlarının tehdit altında olması, temel hizmetlerin kesilmesi veya aksaması ve geçim kaynaklarının kaybedilmesi neticesinde ekonomik sorunların ortaya çıkması şeklinde özetlenebilir. Katılımcıların büyük çoğunluğu Türkiye’ye sınırdan giriş yapmış, bir kısmı ise uçak veya gemi yolculuğunu tercih etmiştir. Sınırdan gelenler, göç güzergahını daha güvenli kılmak ve olası riskleri azaltmak amacıyla, insan kaçakçıları vasıtasıyla Türkiye’ye gelmişlerdir.

Tablo 1. Katılımcılara İlişkin Bazı Demografik Bilgiler

\begin{tabular}{lllll}
\hline & Yaş & Cinsiyet & Ĕ̈itim Durumu & Vatandaşlık durumu \\
\hline $\mathbf{K}-\mathbf{1}$ & 26 & Erkek & Üniversite Ö̆ğrencisi & Geçici koruma / Vatandaşlık 5. aşama \\
\hline $\mathbf{K}-\mathbf{2}$ & 25 & Kadın & Üniversite Mezunu & T.C. Vatandaş1 \\
\hline $\mathbf{K}-\mathbf{3}$ & 30 & Erkek & Üniversite Mezunu & Geçici koruma / Vatandaşlık 4. aşama \\
\hline $\mathbf{K}-\mathbf{4}$ & 22 & Erkek & Üniversite Öğrencisi & T.C. Vatandaş1 \\
\hline $\mathbf{K}-\mathbf{5}$ & 37 & Erkek & Lise Mezunu & T.C. Vatandaş1 \\
\hline
\end{tabular}


Akçapar ve Calisan 229

\begin{tabular}{lllll}
\hline K-7 & 24 & Erkek & Üniversite Öğrencisi & Geçici koruma \\
\hline K-8 & 32 & Kadın & Lise Mezunu & Geçici koruma \\
\hline K-9 & 44 & Kadın & İlkokul Mezunu & Geçici koruma \\
\hline K-10 & 38 & Kadın & Lise Mezunu & Geçici koruma \\
\hline K-11 & 64 & Erkek & Üniversite Mezunu & T.C. Vatandaş1 \\
\hline K-12 & 33 & Erkek & Lise Mezunu & Geçici koruma \\
\hline K-13 & 34 & Kadın & Lise Mezunu & Geçici koruma \\
\hline K-14 & 30 & Kadın & İlkokul Mezunu & Geçici koruma / Vatandaşlık 2. aşama \\
\hline K-15 & 32 & Erkek & Üniversite Mezunu & Geçici koruma / Vatandaşlı 5. aşama \\
\hline K-16 & 30 & Erkek & Üniversite Mezunu & Geçici koruma / Vatandaşlık 4. aşama \\
\hline K-17 & 41 & Erkek & Lise Mezunu & Geçici koruma \\
\hline K-18 & 36 & Kadın & Lise Mezunu & Geçici koruma \\
\hline K-19 & 52 & Kadın & İlkokul Mezunu & Geçici koruma \\
\hline K-20 & 27 & Kadın & Lise Mezunu & Geçici koruma \\
\hline
\end{tabular}

Türkiye'nin hedef ülke olarak seçilmesinde en çok dile getirilen nedenler, coğrafi yakınlık ve açık kap1 uygulamasıdır. Başlangıçta kısa süreli olarak göç edeceklerini düşünen bazı katılımcılar, Suriye'deki mevcut rejimin devrilmesi ile birlikte hızlıca ülkelerine dönebilme imkanı verdiği için Türkiye'yi tercih ettiklerini ifade etmişlerdir. Göç yolculuğunda ve Türkiye'ye yerleşme sürecinde en büyük kolaylaştırıcıları, daha önce göç eden veya Türkiye'de yaşayan aile bireyi, akraba ve arkadaş gibi sosyal ağları olmuştur.

“(...) Savass sadece bomba atmak ya da adam öldürmek değil. Ekonomi bitiyor, elektrik, su bunlarn hepsi bitiyor. Yiyecek içecek bitiyor. (...) Hirsı̨llk başlad, insanlar birbirini ibbar etmeye başlad. Kapı komsunla düsman oldun. Diyorlar ki Suriyeliler geldi, savastan korktular, kactular. Eskiden olduğu gibi bir meydanda toplamp savassak kimse kacmaz. Artı savaşöyle değil. Seni tabanca ile vursalar bir sey olmaz. Ama böyle böyle her seyde, her yerde baske olusturuyorlar." $(\mathrm{K} 5,37, \mathrm{E})^{13}$

'Biz burada bir süre kalirn diyorduk. Esad gidince de hemen döneriz diye düsünüyorduk. Bu kadar kalmak gibi bir planımı yoktu yani. Sonra Esad kalinca, IŞID gelince çok kötü oldu her sey. O yüzden artık kalacăgrz: Suriye'ye gitmek zor bu saatten sonra.” $(K 1,26, E)$

Eğitim durumlarına ilişkin veriler incelendiğinde, sekiz katılımcının üniversite mezunu/öğrencisi olduğu görülmektedir. Diğer katılımcıların ise dördü ilkokul mezunu, sekizi lise mezunudur. Katılımcıların çoğu, Suriye'deyken doktor, mühendis, eczacı gibi profesyonel mesleklerde çalışan ve ticaretle uğraşan, orta ve üst sınıfın yaşam tarzını benimseyen kişilerdir. Ülkelerinde sahip oldukları ekonomik sermayeyi, Türkiye'ye gelmelerinde ve buraya yerleşmelerinde kullanmışlardır. Ancak, Suriye'deyken onların yaşam kalitesini yükselten beşeri sermayeleri, Türkiye'de diploma denkliğinin alınamaması ve Türkçe bilmeme gibi sebeplerle geçerliliğini kaybetmiştir. Ekonomik sermayelerinin zaman içinde tükenmesi ve acil para ihtiyacı bu grubun, vasıflarının ve eğitim seviyelerinin çok altındaki işlerde, düşük ücretler karşılığında çalışmasına neden olmuştur. Göç sonrası vasıfsızlaşmanın bir sonucu olarak, sosyo-ekonomik statüleri olumsuz etkilenmiştir. Öte yandan, Suriye'deyken alt gelir grubunun üyeleri olan katılımcıların sınıfsal konumları, her iki yerde de beşeri ve ekonomik sermayeden yoksun oldukları için aynı kalmıştır. Bu iki grup için ortak olan şey ise, kültürel ve sosyal

1 "Beşinci katılımcı, 37 yaşında, erkek" açıklamasına işaret eder. Benzer kodlama diğer katılımcılar için de yapılmıştır. 
sermayelerinin varlığı, bunların bir mücadele pratiği olarak ekonomik sermaye üretme amaçlı kullanilmasidir.

'Ben, Suriye'de bilgisayar mühendisi olarak çallşyordum. Babam da tarm ve ticaretle uğraşıyordu. Buraya gelince, babam rahatsizland, aileme şimdi ben ve erkek kardesim bakmak zorundayz: (...) Buraya geldiğimde, birazparamız vardı, onu kullandık ama sonra çalısmamı gerekti. Ben de tekstilde çalıștım, inşaatta çalıștım, garsonluk yaptım. Suriyelilerin is bulmak için kullandiklar [sosyal medya] gruplar var oradan buluyorum işleri. Denklik alamadım çünkü Suriye'ye gitmem lazım önce. Onu da istemiyorum çünkü bana orada bir şey olsa buradaki aileme ne olacak? Ayrnca alsam bile ne olacak, simdi bilgisayar mühendisi olarak bir Türkü mü çalıstırrlar yoksa Suriyeli birini mi?" (K16, 30, E)

Göç sürecinin katılımcıların hayatlarının her alanında yarattığı radikal dönüşüm, farklı bir sosyal dünyanın yapılarını içselleştirmelerini, öznelliklerini belirli davranış kalıpları, bir diğer deyişle, habitus etrafinda yeniden kurgulamalarını zorunlu kılmıştır (Bourdieu, 1975). Ancak, bunu yapabilmek için belirli ön koşulları yerine getirmek gerekir. Bunlar arasında, emek piyasasına eklemlenmek, barınabilecek bir yer bulmak, sağlık hizmetlerinden yararlanmak ve eğitim almak, bireyin yabancısı olduğu sosyal dünyada kendine bir yer bulmasını sağlar.

Sosyal ve kültürel sermayenin kolaylaştırıcılığında, Suriyeli mülteciler emek piyasasına girmişlerdir. Emek piyasasına eklemlenmek, sosyal uyum sürecinin en önemli basamağıdır. Her ne kadar bu eklemlenme adil ve eşit şartlarda gerçekleşmese de, katılımcılar için barınma, sağlık ve eğitim hizmetlerine erişimin önünü açmıştır. 2014 yılında yılında yürürlüğe giren Geçici Koruma Yönetmelĭğ nin Suriyelilere, istihdam, barınma, sağl1k, eğitim ve diğer kamu hizmetlerine erişim hakkı tanımasıyla yasalar düzeyinde de bir kolaylık sağlanmıştır (Geçici Koruma Yönetmeliği, 2014). Takip eden y1llar içerisinde, belirli kriterlere sahip Suriyeli mültecilere, Türk vatandaşlığı verilmesinin de yasal olarak önü açılmıştır. Bu kriterler; 1) Türkiye’ye yasal olarak giriş yapmak, 2) geçici koruma statüsüne veya ikamet iznine sahip olmak, 3) en az lisans düzeyinde bir diplomaya sahip olmak, 4) bir mesleğe sahip olmak ve 5) herhangi bir suça karışmamış olmak şeklinde özetlenmiştir (Köşer Akçapar \& Şimşek, 2018).

Yapılan görüşmelerde, katılımcıların ortalama altı yıldır Türkiye'de yaşadıkları görülmüştür. Bu süreç içinde, dört katılımc1, telefonla aranarak vatandaşlık için görüşmelere çağrıldıktan sonra Türkiye Cumhuriyeti vatandaşlığı almıştır (Bkz. Tablo-1). Lise mezunu olan bir katılımc1 dışında hepsi yukarıda özetlenen kriterlerin tümünü sağlamaktadır. Köşer Akçapar ve Şimşek'in (2018) tartıştığı gibi, bu katılımcılar için vatandaş olmak, kendini ve geleceğini güvence altına almak ve daha çok haktan yararlanmak demektir. Bu gibi avantajların yanı sıra, katılımcılar, katılımcılar, bazı durumlarda vatandaş oldukları için yerel halktan tepki gördüklerini de aktarmıştır. Görüşülen diğer katılımcılar, geçici koruma statüsü altında kalmakta; ancak aralarında bazılarının vatandaşlık süreçleri devam etmektedir.

\section{“(...) Geçen yul Suriye’ye gideceğim diye Türkiye pasaportu çıardım. Sonra oda arkadaşlarm pasaport çıartamadıklar için bana karşı kötü davrandılar. (...) Bir gün bir tartıs̆ma sırasında bana "geldiniz tepemize çıtınız, Türk vatandaş da oldun, pasaportu da aldın, ob!" dedi." (K2, $25, K)$}

Yönetmeliklerin yasal engellerin birçoğunu ortadan kaldırmasına rağmen, katılımcılar temel haklarından yararlanmak ve hizmetlere erişmek istediklerinde pratikte bazı engellere karşılaşmışlardır. Örneğin, ev sahiplerinin Suriyeli oldukları için evlerini kiralamak istememesi, 
kötü koşullardaki evlere yüksek kira bedelleri istenmesi veya keyfi nedenlerle evden çıkarmalar, ev arama süreçlerinde karşılaştıkları engeller arasında gösterilebilir. Bu tür ayrımcı ve dişlayıc1 davranışlara karşı ise, Suriyelilerin yoğun olarak yaşadıkları mahallerde ev bakmayı veya Suriyeli sosyal ağları vasıtasıyla ev bulmayı kendilerine bir mücadele pratiği olarak seçmişlerdir. Bu stratejiler, onların grup içi bağlarını güçlendirip bir güven alanı oluştursa da, yerel halk ile olan teması azalttığı için sosyal köprülerin kurulmasını engellemektedir (Putnam, 2000).

"Cok kötü evlere çok para istiyorlar. Evde tuvalet yok, mutfak yok diyor ki bu 600 lira. Türklere o kadar demezler. Suriyeli olduğumuz için diyorlar. Abimlerden önce iki kere ev değistirdik. Ev sabibi diyor ki sizden daha fazla veren buldum, çı ın. Biz 400 veriyoruz mesela başka Suriyeli 450 veriyor. Bizi çıkaryor." (K19, 52, K)

Geçici Koruma Yönetmeliği kapsamında, sağlık hizmetlerinin ücretsiz olması erişilebilirliği ve genel memnuniyeti artırmıştır. Bu kararın önemi, Türkiye'ye geldikten sonra bulaşıcı hastalık geçirmiş veya daha önce bu hastalıklara karşı aşı olmadığı için risk altında olan kişilerle yapılan görüşmelerde bir kez daha ortaya çıkmıştır. Bu katılımcıların, kendileri ya da bir yakını hastalandığı zaman sağlık hizmeti alabilmiş olması, hastalığın bulaşma riskini azaltarak genel halk sağlı̆̆ının korunmasına katkıda bulunmuştur. Bununla birlikte, katılımcılar,sağlık hizmetlerinden yararlanırken karşılaştıkları bazı sorunları dile getirmişlerdir. Bunlar ise; hastanelerin kalabalık olması, tercüman sayısının yetersizliği, hizmet veren ya da hizmet alan diğer kişilerin ayrımcı ya da dışlayıcı tutumlar sergilemesi şeklinde özetlenebilir.

\section{Pandemi Etkisi}

Türkiye'nin COVID-19 mücadelesi, 11 Mart 2020 tarihinde ilk koronavirüs vakasının tespiti ile başlamıştır. Bu kapsamda alınan kararlar neticesinde, sağlık hizmetleri salgını kontrol altına almak için yeniden yapılandırılmış, bazı iş yerlerinde faaliyetler durdurulmuş veya esnek çalışmaya gidilmiş, ülke genelinde tüm kademelerde uzaktan eğitime geçilmiş ve seyahat kısıtlaması getirilmiştir (T.C. İçişleri Bakanlığı, 2020a; T.C. İçişleri Bakanlığı, 2020b). Bu kararlardan, halk sağlığ1 açısından en önemli olanı ise 13 Nisan 2020 tarihli ve 2399 sayılı Cumhurbaşkanlığı Kararnamesi'dir. Buna göre, COVID-19 acil hal kapsamına alınarak, sosyal güvence şartı olmaksızın herkesin tanı ve tedaviye erişimi mümkün kılınmıştır (Resmi Gazete, 2020).

Pandemi döneminde tedavi kadar doğru bilgiye erişmek de büyük önem taşımaktadır. Bu doğrultuda, Yabanc1 Uyruklular Poliklinikleri ve Göçmen Sağlı̆̆ Merkezleri aktif bir şekilde göçmen ve mültecilere yönelik olarak hem sağlik hizmeti sunmuş hem de Türkçe, Arapça ve İngilizce olarak bilgilendirme çalışmaları yürütmüştür (Göç Sağlığ1 Dairesi Başkanlığı, 2020). Bunun yanı sıra, Sağlık Bakanı Fahrettin Koca ve bazı kamu kurumlarının sosyal medya hesapları, mülteciler için bir diğer bilgi kaynağı olmuştur. Ancak, yapılan görüşmelerde, katılımcıların bir kısmının, verilen bilginin Arapça olması sebebiyle, güvenilir olmayan kaynaklar üzerinden COVID-19 ile ilgili bilgilere eriştikleri görülmüştür. Yine de, bütün katılımcılar, koronavirüsün yaygın belirtilerini ve salgından korunmak için alınması gereken önlemleri bilmektedir.

Pandemin temel hizmetlerin hepsine erişimi aksatmış olsa da, mülteciler için en yıkıcı etkisi, geçim kaynaklarının kaybedilmesidir. Görüşmeler sırasında, sadece dört erkek katılımcının çalıştığ1 öğrenilmiştir. ${ }^{24}$ Diğer katılımcılar ise, pandemi ile birlikte kendilerinin/hanede çalışan

${ }^{2}$ K-6, K-12, K-16, K-17 
diğer kişilerin işlerini kaybettiğini veya haneye giren toplam gelirlerin azaldığını ifade etmişlerdir. Pandemi öncesinde aldıkları kurum yardımlarının bu dönemde kesilmesi veya düzenli olarak gönderilmemesi de, bu dönemde, katılımcıların mağduriyetlerini artırmıştır.

Geçim kaynakları azalan katılımcılar, pandemi sürecinde düzenli bir iş bulamamışlardır. Bunun neticesinde, var olan kaynakları korumak veya artırmak için belirli yollara başvurmuşlardır. Bunlardan biri, erkek mültecilerin inşaat, mevsimlik tarım, hamallık gibi günlük işler yaparak; kadın mültecilerin ise, bulundukları şehrin iş piyasasına göre değişmekle birlikte, fıstık kırma, boncuk dizme, giysi işleme gibi parça başı işler yaparak gelir elde etmesidir. Hem erkek hem de kadın mülteciler, bu işleri bulmak için sosyal sermayelerini kullanmışlardır. Dolayısıyla, önceden tanıdıkları tarım aracıları, ustabaşları veya diğer Suriyeliler, katılımcıların ekonomik sermayeye erişmelerinde önayak olmuşlardır. Yine de, bu işlerden kazanılan para çok düşük olduğu ve sürekli olmadığı için katılımcılara, masraflarını karşılama imkanı vermemiştir.

"İsler çok az̧aldı. Şimdi bą̧en hamallik yapıyorum burada. Arada inşaatlara gidiyorum. Ama 50-60 lira kazanyorum günde. O da yetmiyor.” (K7, 24, E)

"Kayınvalidem ve görümcem baz̧en komsuya gidiyorlar fistık çıtlamak için. (...) Komşunun kocası da tarimda çalşsyor, o getiriyor işi.” (K18, 36, K)

Yapılan görüşmelerde, katılımcıların aile üyelerinden herkesin göç sürecine katılmadığ1 veya farklı ülkeleri tercih ettikleri görülmüştür. Pandemi öncesinde ve sürecinde, diğer ülkelerde olan bu üyeler arasında bir para akışı vardır. Dolayısıyla, katılımcılar için, ulusötesi ilişki ağları kullanarak finansal destek almak, diğer bir strateji olarak karşımıza çıkmaktadır.

'Bir abim var Kuveyt'te çalısıyor. Oranın para birimi (burada) çok yü̈ksek. O bize para gönderiyor. Bu sekilde yardımo oluyor. (...) Mesela 100 Kuveyt dinar gönderiyor burada 2000 liradan fazla yapyor." (K4, 22, E)

İş kayıpları ve geçim kaynaklarının azalması, masrafların karşılanmasını da olanaksız hale getirmiştir. Bunun bir etkisi, barınma koşullarının değişmesinde ortaya çıkmıştır. Kira ve faturalarını ödemekte zorlanan katılımcılar, giderlerini azaltmak amacıyla yakın çevrelerinden kişilerle evlerini birleştirmişlerdir. Ev birleştirmeler genellikle akraba veya arkadaşlar ile yapılsa da, bazı durumlarda evlilik yoluyla da gerçekleşmiştir. Suriyeli mülteciler için evlilik, hem pandemiden önce hem pandemi sürecinde karşılaştıkları ekonomik sorunlara çözüm olan ve onlara, kısıtlı imkanları birleştirerek, dayanışma şansı tanıyan bir toplumsal eylem olarak karşımıza çıkmaktadır (İncetahtac1, 2020). Bu tür sosyal ağların, en güvenilir dayanışma yolu olarak kişiler üzerindeki yükü azalttığ1 görülmüştür. Öte yandan, hane içindeki toplam nüfusu artırdığı için ev birleştirmelerinin olumsuz etkisi de vardır. Hanede yaşayanların sayıları arttıkça, sosyal mesafenin sağlanması katılımcılar açısından mümkün olmamakta; birinin koronavirüse yakalandığ1 durumlarda hem hanedeki diğger üyeler hem de temasta buldukları kişiler yüksek risk altına girmektedir.

"Burası benim arkadaşımın evi. Onun da kocası öldü. Oğlu Almanya'da. (...) Nisan ayında

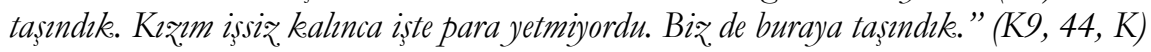

"Yani çalıstrğgyla geçiniyoruz. Bir de eşim evlendi. Dini nikabla... Dedi ki 'evde para yok, ben birini buldum, o da gelecek parası var.' Kadın dul, çocukları ona Katar'dan para gönderiyor. Eşimden de büyük, 52 yaşında." (K8, 32, K) 
Genel halk sağlığının korunması noktasında karşımıza çıkan en kritik bulgu, katılımcıların koronavirüse yakalanmaları veya koronavirüs hastası ile temas halinde olmaları durumunda, karantinaya alınma ve geçim kaynaklarını kaybetme korkusu sebebiyle sağlık hizmetlerinden yararlanmamaları ve işe gitmeye devam etmeleridir. Tablo-2'de her bir katılımcının COVID19 ile ilişkisine yer verilmiştir. Buna göre, riskli olan katılımcılardan sadece beşinin test yaptırdığ1 ve karantinada kaldıkları görülmüş̧ür. Ancak, Tablo-3’ten de görülebileceği üzere, test yaptıranlardan sadece bir tanesi evin geçiminden sorumludur. ${ }^{35} \mathrm{Bu}$ katıllimc hastanede tercüman olarak çalıştığı için zorunlu olarak karantinada kaldığını ifade etmiştir. Diğer katılımcılar ise, hanenin gelirine katkıda bulunmadıkları için karantinada kalabilmişlerdir. Öte yandan, bu kişilerin temaslı olduğu ve belirli semptomlar taşımalarına rağmen test yaptırmaktan kaçınan aile üyeleri, riskli olduklarını saklayarak işe gitmeye devam etmiştir. Çünkü, başka bir geliri olmayan bu aileler için, testin pozitif çıkmasının ardından uygulanacak olan zorunlu karantina, zaten kisitlı olan gelirlerinin tamamen sifirlanmasi anlamina gelmektedir.

Tablo 2. Katılımcıların COVID-19 ile İlişkisi

\begin{tabular}{l|ll}
\hline & Kat1limc1lar & Test Yaptıranlar ve Karantinada Kalanlar \\
\hline COVID-19 pozitif olanlar & K-1, K-2, K-6, K-10, & K-1, K-10, K-16, K-20 \\
& K-16, K-20 & \\
\hline $\begin{array}{l}\text { COVID-19 pozitif olan hasta ile } \\
\text { temas halinde olanlar }\end{array}$ & K-4, K-7, K-9, K-12, & K-9 \\
\hline $\begin{array}{l}\text { Enfekte olmayanlar/Temasli } \\
\text { olmayanlar }\end{array}$ & K-3, K-14, K-17, K-11, & \\
\hline
\end{tabular}

"Bizde herkes (COVID-19) oldu ama hastaneye gitmedik. (...) Isse gittik tabii. Ne yapalm, para yok çalısmazsak 15 gün bize kim bakacak? Maskeyi takerp gittik. (...) Karantinaya alınacağız diye çok korktuk. Karantinaya alnsaydık yapacak bir şey kalmazdı. Evde beklerdik o zaman da açlketan ölürdük. Yok para ne yapacaksin? Adam bastalanırsa da ölecek, çalısmazsa da ölecek." (K6, 51, E, Enfek.te)

"Ben korona oldum. Test yaptılar. Pozitif çıtı. Ilac verdiler. Karantinada kaldım. (...) Yani

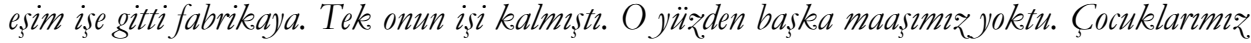
var. Gitmesi gerekti. Ama kendini korudu yani. Maskesini taktı." (K20, 27, K, Enfekte)

Tablo 3. Enfekte veya temaslı olan katılımcılara ilişkin bazı veriler

\begin{tabular}{lllll}
\hline Cinsiyet & $\begin{array}{l}\text { Hanesinin geçim kaynağı kendisi } \\
\text { mi? }\end{array}$ & $\begin{array}{l}\text { Test yaptırdı } \\
\text { mı? }\end{array}$ & $\begin{array}{l}\text { Karantinaya uydu } \\
\text { mu? }\end{array}$ \\
\hline K-1 & Erkek & Hayır & Evet & Evet \\
\hline K-2 & Kadın & Evet & Hayır & Evet \\
\hline K-4 & Erkek & Hayır & Hayır & Hayır \\
\hline K-6 & Erkek & Evet & Hayır & Hayır \\
\hline K-7 & Erkek & Evet & Hayır & Hayır \\
\hline K-9 & Kadın & Hayır & Evet & Evet \\
\hline K-10 & Kadın & Hayır & Evet & Hayır \\
\hline K-12 & Erkek & Evet & Hayır & Hayır \\
\hline K-13 & Kadın & Hayır & Hayır & Hayılr \\
\hline K-14 & Kadın & Hayır & Hayır & Hayır \\
\hline K-16 & Erkek & Evet & Evet & Evet \\
\hline
\end{tabular}




\begin{tabular}{lllll}
\hline K-17 & Erkek & Evet & Hayır & Hayır \\
\hline K-20 & Kadin & Hayır & Evet & Evet \\
\hline
\end{tabular}

Suriyeli mültecilerin emek piyasasında yaşadıkları ve onları sağlık haklarından mahrum bırakan bu kırılganlıkları genellikle gözden kaçmaktadır. Bu durum, benzer bir göç hikayesi ve yoksulluğu paylaşan katılımcıları, kendi grup içi bağlarını güçlendirerek, yaşadıkları sorunlara dayanışma yoluyla çözüm üretmeye itmiştir. Nitekim, katılımcılar sadece kendilerinin değil, aynı zamanda, diğer arkadaşlarının da COVID-19 sebebiyle riskli olan sağlık durumlarını, iş yerindeki diğer personelden saklamaktadır. Özellikle, aynı işi yaptıkları farklı etnik kökene sahip grupların varlı̆̆1 söz konusu olduğunda, bu tutum mevcut işi korumak için hayati bir öneme sahip olmaktadır. Her ne kadar katılımcıların grup içi dayanışmaları güçlü ise de, farklı etnik gruplar ile emek piyasasındaki yerlerini korumak adına tam bir rekabet halindedirler (Dedeoğlu, 2018).

"Yazın insaatta biri korona oldu. Şu an iyi ama zaten o bic aymlmadi ișten. Calısmak zorunda cocuklar var. Biz ondan uqak durduk, maske taktık. O sekilde kendimizi koruduk. (...) Inşaattakiler, bilmiyordu. Cünkü bilseler iz̨in vermezler çalısmasma. (...) Ustabaş iz̨in vermez. Bir de Kürtler var mesela. Onlarla çalısıyoruz. Onlar izin vermez. Zaten bir şey olunca hemen gidip şikayet ediyorlar su Suriyeli böyle yaptı diye. (...) Bize diyorlar ki siz. geldiniz fiyat kurdını, siz geldiniz is kalmadr. Ondan sevmiyorlar bizi." (K7, 24, E, Temasli)

"Ben hasta olmadim ama diğer (Suriyeli) iş̧̧ilerden korona olan vard. Ama onlar karantinaya girmediler. Isse geldiler. (...) Issveren falan bilmiyordu. Biz de söylemedik ürretsiz izine cıkarmasinlar diye." (K17, 41, E, Temash)

Pandeminin, geçim kaynaklarını azaltıcı etkisi ve bağlantılı olarak barınma koşullarını değiştirmesinden bahsettikten sonra, mültecilerin sağlık ve eğitim hizmetlerine erişimlerini nasıl dönüştürdüğüne de bakılmalıdır. Katılımcıların, sağlık hizmetlerinden geçim kaynaklarını kaybetmemek için yararlanamadıkları yukarıda ifade edilmiştir. Bunun yanı sıra, katılımcılar, şehir hastaneleri sistemi ile hastanelerin şehir merkezinden uzak yerlere taşınmasının, hastaneye ulaşım süresini artırdığını ve ulaşımı zorlaştırdı̆̆ını belirtmiştir. Katılımcıların, sağlık merkezlerine birden fazla toplu taşıma aracına binerek gidebilmeleri, seyahatleri sırasında koronavirüse yakalacakları yönünde bir korku oluşturmuştur. Aynı korkuyu, hastanelerin kalabalık olması sebebiyle hizmet alırken de yaşadıklarını belirten katılımcılar, bu sebeple, acil bir durum olmadığ1 sürece tedavi olmayı ve kontrole gitmeyi ertelemektedirler. Kronik hastalıkları olan ve düzenli ilaç kullanan kişilerin bu endişeler ile sağlık hizmetlerinden yararlanamamaları, onların genel sağlık durumlarını daha çok tehdit etmektedir. Sağlık hizmetlerine erişimi engelleyen bir diğer husus da "Suriyelilerin COVID-19 döneminde hastanelerde tedavi edilmediğì" veya "COVID-19 tedavisi için Suriyelilerden para istendiği" gibi yanlış bir bilgilerin varlığıdır. Salgın ile ilgili gelişmeleri güvenilir olmayan kaynaklardan takip eden kişilerin, bu tür bilgilere daha çok maruz kaldığı görülmüştür. Özellikle eğitim durumu düşük katılımcılar, karşılaştıkları bilgilerin doğruluğunu teyit edemedikleri için, birçok yanlış bilginin mağduru olmaktadır.

"(Hastaneye) gitmedik çünkü hastalanmak istemedik. Otobüsle gitmemiz. lazฺm. Otobüsler çok. kalabalık, yani hastaneler de çok kalabalık. Kücüle rahatsı̨llklar olunca evde mesela bitkisel seyler hazırlyyoruz: (...) Hamilelik kontrollerine de gitmedim. Ya hastalanirsak..." (K14, 30, K) 
"Şimdi biz minibüsle gidiyorduk ama koronadan dolayn minibüse gidemiyoruz. Taksi tutmamı. lą̧m. Cünkü annem babam korona olursa ölür yani. Komşum (tercüme için) da gelmiyor. Korona olmaktan korkuyor. Yani tercüman yok, ulasım yok ama doktora da gitmemiz lazım.” (K19, 52, K)

Göç etme ve yerleşme süreçleri sırasında, bazı katılımcılar, kendilerinin ya da diğer aile üyelerinin eğitimden bir süre mahrum kaldıklarını ifade etmişlerdir. Ancak, 2014 yılında Geçici Koruma Yönetmeliği'nin yürürlüğe girmesi ve birçok aktörün dahil olduğu sosyal uyum süreci, zaman içinde eğitimdeki aksaklıkları onararak daha çok çocuk ve gencin eğitim sistemine dahil olmasını sağlamıştır. Bu sebeple, pandemi öncesi dönemde, hane içindeki çocuk ve gençlerin eğitim hakkından yararlanmalarında ve eğitim hizmetlerine erişmelerinde önemli bir sorun yaşamadıklarını öğrenilmiştir. Ayrıca, Türkçeyi çok iyi öğrenmeye başladıkları için çocukları, Suriyeliler ve yerel halk arasındaki iletişim ve etkileşim alanlarını artırmaları sebebiyle, sosyal köprülerin kurulmasında önemli aktörler olarak görmek mümkündür.

Pandemi sürecinde yüz yüze eğitime ara verilerek uzaktan eğitime geçilmesi, birtakım zorluklar yaratmıştır. Bunlardan biri, bazı hanelerin uzaktan eğitim için gerekli olan internet, telefon, bilgisayar gibi teknik donanımlara sahip olmaması/bunları çocuklarına sağlayamamalarıdır. Bunun neticesinde ise, çocuklar derslere katılamamaktadır. İkinci bir zorluk ise, çocukların derslerini takip etmesi için uygun bir ev ortamının olmamasıdır. Yukarıda, pandemi döneminde yaşanan gelir kayıpları sonucu, masrafları azaltmak için yapılan ev birleştirmelerinden bahsetmiştik. Bunun sonucu olarak kalabalıklaşan evlerde çok ses olması, bir odada çok sayıda kişinin yaşaması ve dikkat dağıtıcı unsurların varlığı çocukların ders çalışmasını engellemektedir. Üçüncü bir zorluk ise, küçük yaşlarda olan ve Türkçe bilmeyen çocukların dersleri takip etmesine yardımcı olacak ve yeterince Türkçe bilen kişilerin olmamasıdır. Ayrıca, Türkçeyi yeni öğrenmeye başlayan öğrenciler, okula gidemedikleri için dili unutmaya başlamışlardır. Bu durum ise, onların derslerini anlamalarını ve ödevlerini yapmalarını zorlaştırarak akademik başarılarının düşmesine neden olmuştur.

"Biz de internet var çok sükeür. Ama ücü de ayn anda EBA TV'yi açmalar ląım. Biri mutfakta, biri salonda biri baska odada. Biri telefondan giriyor, biri bilgisayardan, biri televizyondan bakıyor. Eşim de çok bilmez böyle teknolojiyi. Zaten Türkçe okuması yazması yok. E benim evde olmam lazım. Ben de is takip ediyorum. Coke kötü yani. Biz cocuklar Arapsayn unutmasinlar diye evde Arapşa konuşuyorduk. Ama simdi Türkçeyi unuttular. Tükçe konusuyoruz:" (K5, 37, E)

"Abimin çocuğu okula gidiyordu. Annesinin telefonundan bakzyor ama anlamiyor dersleri. Eskiden okula gittiğinde Türkçesi iyiydi. Şimdi baz̧en ben yardim ediyorum ama benim de kücü̈k cocuklarm var, evin isleri var, her zaman bakamyorum." (K14, 30, K)

Pandeminin eğitim üzerindeki olumsuz etkisinden her çocuk eşit olarak etkilenmemektedir. Kız ve erkek çocuklarının olduğu evlerde, toplumsal cinsiyet mekanizmalarının devreye girdiği, erkek çocuklarının eğitiminin öncelendiği görülmektedir. Kısıtlı olan teknik imkanlar erkek çocuklarının kullanımına sunulmuş; kız çocuklarından ev içi işleri yapmaları, küçük kardeşlerine ve/veya yaşlı bireylere bakmaları beklenmiştir. Aile içindeki iş yükünün, toplumsal cinsiyet rollerine dayalı olarak eşitsiz dağılması, sosyalizasyon sürecinin en kritik aşamalarında olan çocukların bu rolleri içselleştirmelerine neden olmaktadır. Bu durum, 
mevcut cinsiyet eşitsizliklerinin aile içinde yeniden üretilerek sürekli k1lınacağına işaret etmektedir (Bruckauf ve Rees, 2017).

"Ben karantinadayken, temizlik, yemek gibi bütün evin işlerini kı̨ım yaptı.” (K10, 38, K)

"Evde bes çocuk var. Kendi aralarnda telefonlar kullanyorlar dersleri için. Onlarla kızım ilgileniyor. Biz yetisemiyoruz işlere. O yüzden yemekleri de o yapyor, cocuklara da o bakzyor."

$(\mathrm{K} 13,34, \mathrm{~K})$

COVID-19 krizinin toplumsal cinsiyete dayalı bir diğer sorunu da, aile aile içi şiddet vakalarını artırarak görünmez bir pandemi yaratmasıdır (Bettinger-Lopez \& Bro, 2020). Ev ortamının kalabalıklaşması, sokağa çıkma yasakları nedeniyle birçok kişinin aynı yerde bulunması ve geçim kaynaklarının azalması hanede gerilimlere neden olmaktadır. Pandeminin yarattı̆̆ bu gerilimlerden ise, kadınlar ve kız çocukları daha çok etkilenerek aile içi şiddet vakalarına maruz kalmaktadırlar (UN WOMEN, 2020).

Görüşmeler sırasında, kadın katılımcılar, pandemi sürecinde eşlerinin onlara şiddet uyguladığından bahsetmişlerdir. İşsizliğin artmasına bağlı olarak gelir kaynakları azalan erkeklerde, onlardan beklenen "erkeklik görevlerini” yerine getiremedikleri yönünde bir stres ve endişe ortaya çıkmaktadır. Dolayısıyla, aile içinde otoritesi korumak ve "aile reisi" olarak elindeki gücün kaybetmemek adına kadın üzerinde baskı ve şiddet uygulayarak erkekliğini kaybetmediğini göstermeye çalışmaktadır (Mittal ve Singh, 2020). Kadınlar ise, kendi kültürel kodları ve toplumsal cinsiyet rolleri doğrultusunda uygulanan şiddeti normalleştirmektedir. Ayrıca, erkeğe ekonomik olarak bağımlı olmaları maruz kaldıkları şiddete karşı çıkmalarını engellemekte ve şiddeti kabullenmelerine neden olmaktadır.

"Hiçbir sebep yokken bana bağrryordu. Yani, benim kocam çok iyi birisidir, hep iyi niyetlidir. Cok zor zamanlardan gectik, sevdiklerimizi, statümüzü, ülkemizi kaybettik. Bu yüzden yaptıklar anlaşılır. Yani bazı șeyler yaptı ama aslinda yapmak istememiştir. (...) Bir gün ondan masraflar için para istedim diye beni masaya itmişti. Bir gün de, bijabım yurtıldiğ için söyleniyordum. O da sinirlendi ve saçlarm kesti. Bütün gece ağladım. Sonra geldi defalarca özür diledi." (K10, 38, K)

"Evde en çok bana bağıryyordu. Yemek, çamaşır beğenmiyor yani. Cocuklar oyun oynuyor, bana kiziyordu. Cok sükü̈r gecti şimdi. Bir kere şiddet uygulad. Ama benim yüzümden. Cok elektrik faturasi geldi geldi diye babası, kaynnvalideme, bana, yengeme tokat attı. Ben de o sirada ütüyü gömleğin üzerinde unuttuğum için gömlek yanmıs. Gömleği saklayacaktım. O sirada eşim gördü. Dedi sen bir seyi yapamyyorsun nasil kar aldık seni. Sonra o zaman vurdu yani işte yere düstüm.

Tekme attı." (K14, 30, K)

\section{Sonuç}

Birleşmiş Milletler Kalkınma Programının 1994 yılındaki İnsani Kalkınma Raporu’nda, devlet güvenliği ile birlikte, insani güvenliğin de sağlanması gerektiği önemle vurgulanır. Göçe zorlanan/maruz kalan bireyler ise, insan güvenliğinin sağlanamadığ1; dolayısıyla belirli zafiyetlerin olduğu durumların varlığına işaret eder (Köşer Akçapar, 2012). Bir diğer deyişle, mülteci ve göçmenlerin bu zafiyet durumlarının mağdurlarıdır. Her ne kadar, ev sahibi ülkeye yerleşmeleriyle süreç içinde mağduriyetler giderilmeye çalışılsa da, herhangi bir riskin ve tehlikenin ortaya çıkması, onları çoklu kırılganlıklar ile başbaşa bırakmaktadır. Nitekim, 
modernitenin 21. yüzyıldaki karanlık yüzünü simgeleyen COVID-19 pandemisinden en olumsuz etkilenen grupların, mülteciler ve göçmenler olması tesadüf değildir.

Halk sağlı̆̆1, toplumun ayrılmaz bir parçası haline gelen mülteci ve göçmen sağlı̆̆ından bağımsız olarak düşünülemez. Bu sebeple, pandeminin bu grupların hayatlarında yarattı̆̆1 risklerin tespit edilmesi, hassasiyetlerinin ve kırılganlıklarının ortaya çıkarılması gereklidir. Bu çalışma ise tam olarak bu amaç doğrultusunda, Suriyeli mülteciler deneyimlerine odaklanarak yürütülmüştür. Çalışma sonucuna göre, sosyal uyum çabalarının bir ürünü olarak, Suriyeli mülteciler, zaman içinde çalışma ve eğitim hayatına eklemlenmiş, yerel halkla etkileşimleri artarak gündelik hayatta daha görünür hale gelmişlerdir. Yaşam şartlarında görülen bu iyileşme ise, pandeminin başlaması ile birlikte sekteye uğramıştır.

Pandemi süreci, Suriyeli mültecilerin tüm temel hak ve hizmetlere erişimini sınırlandırmıştır. Bunun neticesinde ise, mevcut yaşam koşullarını giderek kötüleşmiştir. Ancak, yaşanan en büyük sorun, iş piyasasına erişim ve geçim kaynaklarının azalması ile ilişkilidir. Bu durum, barınma koşulları, eğitime erişim ve mültecilerin kendi sağlı̆̆ını etkilediği gibi, aynı zamanda, genel halk sağlığını da tehdit etmektedir. Mültecilerin koronavirüse yakalandıklarını veya temaslı olduklarını saklayarak mevcut veya günlük işlerine gitmeye devam etmeleri, gündelik hayatın her alanında temas halinde oldukları kişilerin virüsü kapmasına veya taşımasına neden olabilir. Bu durum, mültecilerin, halk sağlığını tehdit ettikleri ve pandemi ile mücadeleyi yavaşlattıkları yönünde yanlış bir algı sonucu günah keçisi ilan edilmelerine neden olmaktadır. Ancak, mültecilerin karantinadan kaçınmalarının temelinde de başka bir risk olduğu unutulmamalıdır. Çoğunun bağımlı nüfusun fazla olduğu evlerde yaşadığı, kira ve gida gibi belirli masrafları olduğu ve zaten düzensiz işlerde çok düşük ücretler karşıllğında çalıştıkları göz önüne alındığında, zorunlu karantina döneminde veya sonrasında geçim kaynaklarının kaybedilmesi bu kişiler için derin bir yoksulluktan başka bir şey değildir.

Çalışma bulgularından çıkarılabilecek bir diğer sonuç ise, pandeminin mültecilerin her biri üzerindeki etkisinin, kesişimsellik boyutunun öne çıkması ve cinsiyet, eğitim durumu, sınıf gibi değişkenler etrafında farklılaşmasıdır. Çevirim içi görüşmelerde aktarılabildiği kadarıyla, kadınlar ve kız çocukları, pandemi döneminde kısıtlı kaynaklardan dışlanmış, eğitim hakkından mahrum bırakılmış ve aile içi şiddetin hedefi olmuşlardır. Dolayısıyla, mülteciler arasında pandeminin olumsuz etkilerine en çok maruz kalan grubun, kadınlar ve kız çocukları olduğunu söylemek mümkündür. Bireylerin eğitim seviyesindeki farklılaşma ise özellikle pandemi ile ilgili bilgilere erişim noktasında bir kırılganlık yaratmaktadır. Düşük eğitim seviyesine sahip ve Türkçe bilmeyen kişiler, sosyal medyada hızlıca dolaşıma sokulan doğru olmayan bilgilere inanarak hizmetlerden uzak kalmışlardır. Öte yandan eğitim seviyesi yükseldikçe, bireyler bu bilgileri teyit edebilme yetisi kazanmakta ve bu yüzden salgından kendilerini daha çok koruyabilmektedirler.

Pandemide geçim kaynaklarının azalması ya da bitmesi, bireyleri sınıfsal konumlarına göre değişen düzeylerde etkilemiştir. Orta ve üst sınıftan gelen mülteciler için ekonomik sermayeleri, onları işsizliğın getirdiği baskıdan kurtarmıştır. Ancak, alt gelir grubundan kişiler, kendilerini güvence altına almaya yetecek herhangi bir ekonomik sermayeleri olmadığı için pandemiyle birlikte aşırı yoksulluğa sürüklenmektedirler. Pandeminin etkileri bakımından, vatandaş olan ve olmayan kişiler belirgin bir farklılık olsa da, bu farklılığ1 vatandaşlık statüsü ile açıklamak doğru olmaz. Görüşmelerde, vatandaş olan kişilerin; eğitimli olmak, orta ve üst sınıftan gelmek, finansal olarak destek gördükleri ulusötesi ilişki ağlarına ve/veya Türkiye'de 
ev ve dükkan gibi belirli taşınmazlara sahip olmak şeklinde ortak noktaları olduğu görülmüştür. Dolayısıyla, bu belirgin farklılık da sınıfsal konumlar üzerinden açıklanabilir.

Pandemi ile mücadele kapsamında, toplumun her kesiminin ücretsiz olarak COVID-19 ile ilgili sağlık ihtiyaçlarının karşılanmasının önünün açılması, genel halk sağlığının korunması açısından son derece önemli bir karardır. Ancak, pandeminin sadece bir sağlık krizi olmadığını unutmamak gerekir. Bu sebeple, pandeminin geçici koruma altındaki Suriyeliler ve uluslararası koruma altındaki diğer bireyler üzerindeki çok boyutlu etkisini göz önüne alan, kırılganlıklarına ve hassasiyetlerine cevap veren ve aşılanma dahil karşılaştıkları riskleri azaltan bir eylem planının hazırlanması oldukça önemlidir. Bu noktada, toplumun hiçbir kesiminin geride bırakılmadığı insan odaklı bir perspektif, pandeminin sona ermesi ve tekrar normalleşme sürecine girilebilmesi açısından elzemdir.

\section{Kaynakça}

Ahmed, A., Jordan, M. ve Semple, K. (2020). A closed border, dashed hopes and a looming disaster. The New York Times.

https://www.nytimes.com/2020/03/21/world/americas/coronavirus-mexico-border-migrants.html

Akyıldız, Ş. (2020). COVID-19 işgücü piyasasını nasıl etkiledi? Ankara: TEPAV. https://www.tepav.org.tr/tr/ekibimiz/s/1168/Senay+Akyildiz

Armstrong, P. (1996). The feminization of the labour force: Harmonizing down in a global economy. İçinde I. Bakker (Der.), Rethinking, Restructuring: Gender and Change in Canada (ss. 29-54). University of Toronto Press.

Banulescu-Bogdan, N., Benton, M. ve Fratzke, S. (2020). Coronavirus is spreading across borders, but it is not a migration problem. Migration Policy Institute. https://www.migrationpolicy.org/news/ coronavirus-not-a-migration-problem

Beck, U. (1992). Risk Society: Towards a New Modernity. London: Sage Publications.

Bettinger-Lopez, C. ve Bro, A. (2020). A double pandemic: Domestic violence in the age of COVID19. Council on Foreign Relations. https://perma.cc/UDY9-RRYE

BMMYK. (2020). UNCHR Türkiye İstatistikleri. UNCHR BM Mülteci Örgütü - Türkiye: https://www.unhcr.org/tr/unhcr-turkiye-istatistikleri

Bourdieu, P. (1975). The specificity of the scientific field and the social conditions of the progress of reason. Information (International Social Science Council), 14(6), 19-47.

Bozok, N., \& Bozok, M. (2020). "Pandemi Mevcut Sorunları Derinleştirdi”: İstanbul'da Kayıtdışı Afgan Göçmenler, Sağlık, Hastalık ve Kovid-19 Pandemisi. Göç Dergisi, 7(2), 165-188. https://doi.org/10.33182/gd.v7i2.728

Braun, V. ve Clarke, V. (2006). Using thematic analysis in psychology. Qualitative Research in Psychology, 3(2), 77-101.

Bruckauf, Z. ve Rees, G. (2017). Children's participation in housework: Is there a case of gender stereotyping? Evidence from the International Survey of Children's Well-Being. https://www.unicef-irc.org/publications/898-childrens-involvement-in-housework-is-there-acase-of-gender-stereotyping-evidence.html

Chen, Y. Y. (2020). Migrant health in a time of pandemic: Fallacies of us-versus-them. İçinde Colleen M Flood vd, (Der.), Vulnerable: The Law, Policy And Ethics of COVID-19 (ss.407-418). University of Ottawa Press.

Chetail, V. (2020). Crisis without borders: What does international law say about border closure in the context of Covid-19? Frontiers in Political Science. doi:https://doi.org/10.3389/fpos.2020.606307

Creswell, J. W. (2015). Nitel Araştırma Yöntemleri: Beş Yaklaşıma Göre Nitel Araştırma Ve Araştırma Deseni. M. Bütün, ve S. B. Demir, Çev. Ankara: Siyasal Kitabevi.

Dedeoğlu, S. (2018). Tarımsal üretimde göçmen işçiler: Yoksulluk nöbetinden yoksulların rekabetine. Çalışma ve Toplum, 56(1), 37-65. 
Delibaş, K. (2015). Risk Toplumu: Belirsizlik ve Söylentiler Sosyolojisi. İstanbul: Ayrıntı Yayınları.

Dempster, H., Ginn, T., Graham, J., Ble, M. G., Jayasinghe, D. ve Shorey, B. (2020). Locked down and left behind: The impact of COVID-19 on refugees' economic inclusion. Center for Global Development, Refugees International, and International Rescue Committee. https://www.cgdev.org/publication/locked-down-and-left-behind-impact-covid-19-refugeeseconomic-inclusion

Elisabeth, M., Maneesh, P.S. ve Michael, S. (2020). Refugees in Sweden during the Covid-19 pandemic - The need for a new perspective on health and integration. Frontiers in Public Health, 8. https://doi.org/10.3389/fpubh.2020.574334

Geçici Koruma Yönetmeliği. (2014). Resmi Gazete No.29153. https://www.resmigazete.gov.tr/eskiler/2014/10/20141022-15-1.pdf

Giddens, A. (1991). The Consequences of Modernity. Stanford University Press.

GÍGM. (2021). Geçici Koruma. T.C. İçişleri Bakanlığ1 Göç İdaresi Genel Müdürlügü: https://www.goc.gov.tr/gecici-koruma5638

Göç Sağlığ1 Dairesi Başkanlığ1. (2020). Halk Sağlığ1 Genel Müdürlügü: https://hsgm.saglik.gov.tr/tr/gocsagligi-anasayfa

Guadagno, L. (2020). Migrants and the COVID-19 pandemic: An initial analysis. International Organization for Migration, Migration Research Series, (60). https://publications.iom.int/books/mrs-no-60-migrants-and-covid-19-pandemic-initial-analysis

Guterres, A. (2020). The COVID-19 crisis is an opportunity to reimagine human mobility. United Nations: https://www.un.org/en/coronavirus/covid-19-crisis-opportunity-reimagine-humanmobility

ILO. (2020). ILO Monitor: COVID-19 and The World of Work. Sixth Edition Updated Estimates and Analysis. https://www.ilo.org/ankara/areas-of-work/covid-19/WCMS_755910/lang--en/index. htm

İncetahtac1, N. (2020). Gaziantep'teki Suriyeli ailelerin baş etme stratejileri. Gažiantep University Journal of Social Sciences, 2, 1-27.

Jamil, H., Fakhoury, M., Yamin, J., Arnetz, J. ve Arnetz, B. (2016). Determinants of employment among well-educated refugees before and after the 2007 U.S. economic recession. Letters in Health \& Biological Sciences 1(1).

Kirişçi, K. ve Erdoğan, M. M. (2020). Turkey and COVID-19: Don't forget refugees. Brookings: https://www.brookings.edu/blog/order-from-chaos/2020/04/20/turkey-and-covid-19-dontforget-refugees/

Kluge, H. H., Jakab, Z., Bartoviz, J., D'Anna, V. ve Severoni, S. (2020). Refugee and migrant health in the COVID-19 response. The Lancet. https://doi.org/10.1016/S0140-6736(20)30791-1

Köşer Akçapar, Ş. (2020). COVID-19 sürecinde diaspora ilişkileri ve göç yönetimi. https://www.memurlar.net/common/news/documents/943483/buro-analiz.pdf

Köşer Akçapar, Ş., ve Şimşek, D. (2018). The politics of Syrian refugees in Turkey: A question of inclusion and exclusion through citizenship. Social Inclusion, 6(1), 176-187

Köşer Akçapar, Ş. (2012). Uluslararası göç alanında güvenlik algılamaları ve göçün insani boyutu. İçinde G. S. Ihlamur-Öner ve N. A. Şirin Öner (Der.), Küreselleşme Cağında Göç: Kavramlar, Tartısmalar (ss. 563-575). İstanbul: İletişim Yayınları.

Krahn, H., Derwing, T., Muldder, M. ve Wilkinson, L. (2000). Educated and underemployed: Refugee integration into the Canadian labour market. Journal of International Migration and Integration, 1(1), 59 84.

Matoo, A., Neagu, I. C. ve Özden, C.. (2006). Brain waste? Educated immigrants in the US labor market. Journal of Development Economics, 87(2), 255-269. https://doi.org/10.1016/j.jdeveco.2007.05.001

Merriam, S. B. (2009). Qualitative Research a Guide to Design and Implementation. San Fransisco, CA: JosseyBass.

Mittal, S., ve Singh, T. (2020). Gender-based violence during COVID-19 pandemic: A mini-review. Frontiers in Global Women's Health, 1(4) 
https://www.frontiersin.org/articles/10.3389/fgwh.2020.00004/full?utm_source=CAL+Newsletter \&utm_campaign $=345 \mathrm{c} 81 \mathrm{cfbd}-$

EMAIL_CAMPAIGN_2018_12_14_10_26_COPY_01\&utm_medium=email\&utm_term=0_1be $789435 \mathrm{a}-345 \mathrm{c} 81 \mathrm{cfbd}-$

MUDEM. (2020). COVID-19 Kriz̨i Sürecinde Türkiye'deki Mültecilerin Durum Analiž. Mülteci Destek Derneği - Refugee Support Center.

OECD. (2020). What is the Impact of the COVID-19 Pandemic on Immigrants and Their Children? https://read.oecd-ilibrary.org/view/?ref=137_137245-8saheqv0k3\&title=What-is-the-impact-ofthe-COVID-19-pandemic-on-immigrants-and-their-children $\% 3 \mathrm{~F}$

Özkul, D. (2020). COVID-19 Salginı Süreci ve Sonrası için Düzensiz. Gögmen, Sı̆ğnmacı ve Mültecilere Yönelik Politikea Önerileri. İstanbul Politik Araştırmalar Enstitüsü. https://d4b693e1-c592-4336-bc6a36c134d6fb5e.filesusr.com/ugd/c80586_390a03e9b49b4bb7a609d0a3d0f615c1.pdf

Putnam, R. (2000). Bowling Alone: The Collapse and Revival of American Community. NY: Simon and Schuster.

Relief International. (2020). Impact of the COVID-19 Outbreak on Syrian Refugees in Turkey. https://reliefweb.int/sites/reliefweb.int/files/resources/76504.pdf

Resmi Gazete. (2020). https://www.resmigazete.gov.tr/eskiler/2020/04/20200414.pdf

Salmani, I., Seddighi, H. ve Nikfard, M. (2020). Access to health care services for Afghan refugees in Iran in the COVID-19 pandemic. Disaster Medicine and Public Health Preparedness, 14(4), e13-e14.

Scharff, C. (2016). Gender and neoliberalism: Young women as ideal neoliberal subjects. İçinde S. Springer, K. Birch, ve J. MacLeavy (Der.) Handbook of Neoliberalism (ss. 245-254). London: Routledge.

SGDD. (2020). COVID-19 Salgmmn Türkiye'de Mülteciler Üzerindeki Etkisinin Sektörel Analizi. Sı̆̆ınmacılar ve Göçmenlerle Dayanışma Derneği.

Shields, J. (1996). Flexible work, labour market polarization and the politics of skills training and enhancement. İçinde T. W. Dunk, S. McBride, ve R. W. Nelson (Der.), The Training Trap: Ideology, Training and The Labour Market (ss. 53-72). Fernwood Publishing.

Sirkeci, I., Özerim, M. G., ve Bilecen, T. (2020). Editörden: KOVID-19'un Uluslararası Hareketlilik ve Göçmenliğe İlişkin Etkisi Üzerine. Göç Dergisi, 7(1), 1-8. https://doi.org/10.33182/gd.v7i1.688

Sirkeci, I., ve Yüceşahin, M. M. (2020). Göç ve Koronavirüs: Nüfus Hareketliliği Verileri Üzerinden KOVID-19 Salgınının Analizi. Göç Dergisi, 7(1), 9-34. https://doi.org/10.33182/gd.v7i1.679

Standing, G. (2014). Prekarya Yeni Teblikeli Simf. E. Bulut, Çev. 6. Baskı. İletişim.

T.C. İçişleri Bakanlığı. (2020a). Bakanlı̆̆ımı 81 il valiliğine koronavirüs tedbirleri konulu ek bir genelge daha gönderdi. https://www.icisleri.gov.tr/bakanligimiz-81-il-valiligine-koronavirus-tedbirlerikonulu-ek-bir-genelge-daha-gonderdi

T.C. İçişleri Bakanlığı. (2020b). Koronavirüs ile mücadele kapsamında - Yeni kisıtlama ve tedbirler genelgeleri. https://www.icisleri.gov.tr/koronavirus-ile-mucadele-kapsaminda-sokaga-cikma-kisitlamalari--yeni-kisitlama-ve-tedbirler-genelgeleri

T.C. İçişleri Bakanlığı. (2020b). Koronavirüs ile mücadele kapsamında - Yeni kisıtlama ve tedbirler genelgeleri. https://www.icisleri.gov.tr/koronavirus-ile-mucadele-kapsaminda-sokaga-cikma-kisitlamalari--yeni-kisitlama-ve-tedbirler-genelgeleri

UN WOMEN. (2020). COVID-19 and Ending Violence Againt Women. bttps://wmw.unwomen.org//media/ headquarters/attachments/sections/library/publications/2020/issue-brief-covid-19-and-ending-violenceagainst-women-and-girls-en.pdf?la $=$ en 6 ws $=5006$

UNCTAD. (2020). The Least Developed Countries Report 2020. Productive Capacities For New Trades. https://unctad.org/system/files/official-document/ldcr2020_en.pdf

Vearey, J., Hui, C., ve Wickramage, K. (2019). Migration and health: Current issues, governance and knowledge gaps, İçinde M. McAuliffe, ve B. Khadria, World Migration Report, (ss. 212-232). IOM.

WHO. (2020). WHO Director-General's opening remarks at the media briefing on COVID-19. World Health Organization: who.int/director-general/speeches/detail/who-director-general-s-opening-remarksat-the-media-briefing-on-covid-19---11-march-2020 
Akçapar ve Calışan 241

WHO. (2021). WHO Coronavirus Disease (COVID-19) Dashboard. World Health Organization: https://covid19.who.int/

World Bank. (2020). Poverty and Shared Prosperity 2020: Reversals of Fortune. Washington DC. https://openknowledge.worldbank.org/bitstream/handle/10986/34496/9781464816024.pdf

\section{EXTENDED ABSTRACT IN ENGLISH}

\section{Growing Vulnerabilities in the Neoliberal Order: Refugee Health During the Pandemic}

Shortly after the first cases emerged in China, the COVID-19 pandemic has turned into a multidimensional crisis affecting societies and communities all around the world. Many governments have introduced an escalating range of policies and measures dealing with the pandemic in order to both protect public health, and mitigate the economic, social, and psychological impacts of the outbreak. However, many of those measures are not inclusive of asylum seekers, migrants, and refugees who are directly and indirectly exposed to the impacts of this crisis. Prior to COVID-19, these groups already faced a wide range of challenges to access fundamental rights and basic services. During the pandemic period, job losses, poverty, and deprivation has hit them hard by worsening their living conditions and deepening existing inequalities and vulnerabilities.

By referring to the theoretical framework on risk society and neoliberalism, this qualitative study investigates the impact of the pandemic on Syrians under temporary protection (SuTP). Findings suggest that the pandemic has led to widespread loss of livelihoods and unemployment among SuTPs which has simultaneously decreased their access to services such as shelter, health, and education. Yet, the respondents have devised new coping strategies, such as sharing their homes with other refugees or concealing their contracting with COVID-19 in order to prevent losing their jobs. The loss of livelihoods during or after the quarantine period means to be pushed into extreme poverty for the respondents, given the fact that most of them live in crowded homes with a dependent population, and have certain regular expenses such as rent and food.

The article also underlines the intersectionality dimension of the outbreak by claiming that the brunt of the pandemic is compounded for the women, the poor, and those with lower levels of education, among others. Women and girls have had to bear the highest burden of genderrelated care responsibilities. Some of them have been exposed to domestic violence during the stringent lockdown measures. Since poorer people have fewer coping mechanisms such as economic capital, they have continued to work in jobs and sectors where they are not able to respect social distancing and other basic prevention practices. Moreover, those with lower levels of education and lack of Turkish language ability are also at increased risk of fake news and misinformation related to the COVID-19 which prevent them from accessing primary healthcare.

Ultimately, this study shows that leaving refugees and migrants behind only exacerbates the spread of the pandemic and threats to public health security. Therefore, this study highlights the importance of public health efforts by involving all migrant and refugee groups for a more successful and effective crisis management that contains and mitigates the pandemic and brings the emergency situation to a close as quickly as possible. 


\section{TRANSNATIONAL PRESS
IONDON}

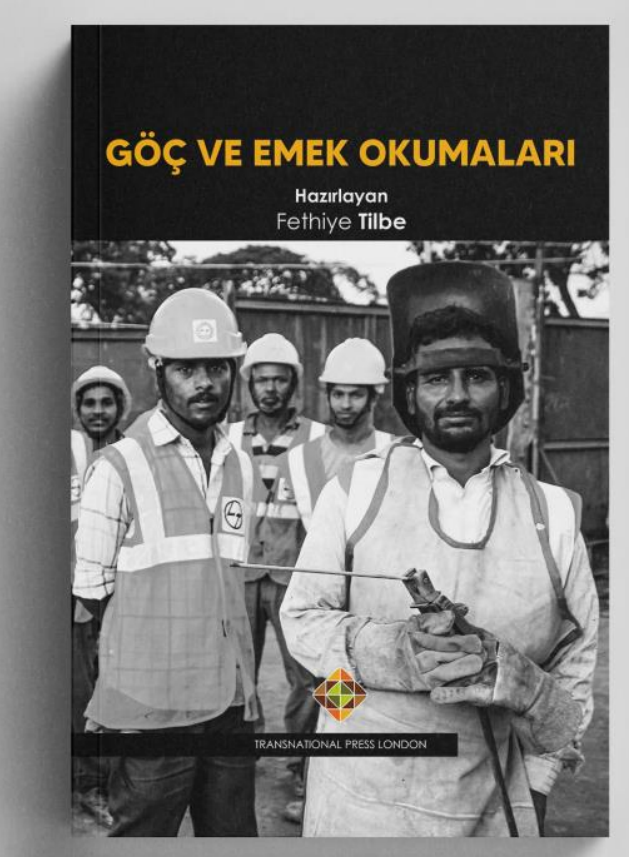

www.tplondon.com

Göç ve Emek Okumaları

Yayına Hazırlayan: Fethiye Tilbe

Published/Yayın tarihi: 22.02.2021 